\title{
PENGEMBANGAN MULTIMEDIA PEMBELAJARAN MATEMATIKA BERBASIS KOMPUTER UNTUK KELAS VIII SMP
}

\author{
Slamet Riyadi, Pardjono \\ SMPN 4 Depok Sleman, Universitas Negeri Yogyakarta \\ arsanla_math@yahoo.com, jpardjono@yahoo.com
}

\begin{abstract}
Abstrak
Pengembangan multimedia pembelajaran matematika ini dilakukan melalui enam tahap, yaitu desain materi, desain software, produksi, evaluasi, uji coba, dan implementasi. Untuk mengetahui kelayakan multimedia pembelajaran yang dikembangkan dilakukan uji coba lapangan dengan angket. Untuk mengetahui keefektifan produk multimedia yang dikembangkan, dilakukan dengan memperbandingkan hasil uji kompetensi antara kelas eksperimen dan kelas kontrol. Subjek uji coba dalam penelitian ini berjumlah 36 orang siswa kelas VIII D SMP N 4 Depok Sleman untuk uji coba lapangan pada kelas eksperimen dan 35 orang siswa kelas VIII B SMP N 4 Depok Sleman pada kelas kontrol. Hasil penelitian menunjukkan bahwa produk multimedia pembelajaran hasil pengembangan termasuk dalam kategori "Baik", persentase siswa yang mencapai ketuntasan belajar setelah menggunakan multimedia pembelajaran hasil pengembangan lebih tinggi $26,51 \%$ dari pada pembelajaran konvensional.
\end{abstract}

Kata kunci: pengembangan, multimedia pembelajaran matematika

\section{DEVELOPING COMPUTER-BASED MATHEMATICS INSTRUCTIONAL MULTIMEDIA FOR YEAR VIII OF JUNIOR HIGH SCHOOL}

\author{
Slamet Riyadi, Pardjono \\ SMPN 4 Depok Sleman, Universitas Negeri Yogyakarta \\ arsanla_math@yahoo.com, jpardjono@yahoo.com
}

\begin{abstract}
The development of mathematics instruction multimedia was conducted in six stages: material design, software design, production, evaluation, try out, and implementation. To determine the feasibility of mathematics instruction multimedia developed field trials conducted by questionnaire. To determine the effectiveness of mathematics instruction multimedia developed, made by comparing the test results of competence between the experimental class and the control class. The subjects of the try out in this research were 36 students of class VIII D SMP N 4 Depok Sleman in large-group try out in experiment class and 35 students of VIII B SMP N 4 Depok Sleman in control class. The result of the research indicates that the developed instructional multimedia is considered as "Good", the percentage of students who mastered the learning material after using the developed instructional multimedia is $26.51 \%$ higher than that of those using conventional instruction.
\end{abstract}

Keywords: development, mathematics instruction multimedia 


\section{Pendahuluan}

Pesatnya kemajuan di bidang teknologi telah mempengaruhi seluruh bidang kehidupan manusia, termasuk bidang pendidikan. Melihat kenyataan tersebut maka pada era globalisasi, di mana teknologi dan informasi sudah menjadi bagian penting dalam kehidupan, maka diperlukan sumber daya manusia yang mempunyai kemampuan kompetitif, adaptif, dan mandiri dalam menghadapi perubahan situasi dan kondisi. Dengan adanya sumber daya manusia seperti itu, diharapkan akan tercapai kehidupan yang damai, sejahtera, dan diperhitungkan dalam masyarakat dunia. Untuk mengantisipasi hal tersebut, maka sistem pendidikan nasional harus mampu menjamin pemerataan pendidikan, peningkatan mutu, serta relevansi dan efisiensi manajemen pendidikan dengan melakukan pembaharuan pendidikan secara terencana, terarah, dan berkesinambungan.

Pendidikan merupakan suatu kegiatan yang berintikan interaksi antar peserta didik dengan pendidik serta berbagai sumber pendidikan (Sukmadinata, 2006, p.24). Setiap guru hendaknya mampu memahami dan mampu melakukan kegiatan inovasi dalam rangka meningkatkan mutu proses pembelajaran, khususnya dalam pemilihan dan pemanfaatan media pembelajaran agar kegiatan pembelajaran dapat berlangsung secara efektif.

Pembelajaran matematika pada semua jenjang pendidikan termasuk pada jenjang SMP perlu mendapat perhatian serius, serta dicarikan terobosan-terobosan baru agar pembelajaran matematika dapat meningkat efektivitasnya. Pembelajaran matematika lebih ditekankan pada eksplorasi dan investigasi matematika. Pembelajaran ini akan membiasakan siswa untuk menggunakan ilmu pengetahuan dalam menyelesaikan berbagai persoalan. Salah satu upaya yang dapat ditempuh adalah dengan melakukan inovasi pada proses pembelajaran, yaitu pembelajaran matematika dengan memanfaatkan multimedia.

Penggunaan media dalam kegiatan pembelajaran sangat penting, mengingat banyaknya kegunaan media dalam kegiat- an pembelajaran, antara lain: (1) memperjelas penyajian pesan agar tidak terlalu bersifat verbalistis; (2) mengatasi keterbatasan ruang, waktu, dan daya indra; (3) mengatasi sikap pasif dari peserta didik. (4) memberikan perangsang, pengalaman dan persepsi yang sama (Sadiman, 2006, pp.17-18). Banyak kalangan percaya bahwa teknologi yang paling canggih untuk pembelajaran melibatkan perpaduan beberapa bentuk media dengan panduan komputer (Seel \& Richey, 1994, p.39). Perpaduan beberapa bentuk media dengan panduan komputer lebih dikenal dengan istilah multimedia pembelajaran berbasis komputer. Namun demikian, pemanfaatan komputer sebagai media pembelajaran masih belum maksimal dilakukan oleh sebagian besar guru.

Guru sebagai perancang pembelajaran dapat memilih komputer sebagai media pembelajaran yang dikenal dengan pembelajaran berbasis komputer (PBK) atau Computer Based Instruction (CBI). Menurut beberapa ahli, pembelajaran berbasis komputer memiliki beberapa kelebihan. Kelebihan multimedia pembelajaran menurut Newby, Stepich, Lehman, dan Russell (2000, p.108) adalah: (1) realistis, peserta didik dapat mendengar kejadian yang nyata seperti apa yang diterima; (2) memotivasi peserta didik meningkatkan sikap positifnya; (3) efektif untuk semua jenis pembelajaran (4) Interaktif, multimedia dapat menyajikan informasi, umpan balik materi dan evaluasi. (5) Konsisten, prosedur dan langkahnya dapat dilakukan oleh semua peserta didik. (6) Terkontrol, dapat dijalankan oleh berbagai tingkatan pemahaman peserta didik. (7) Personal, setiap peserta didik dapat mengendalikan jalanya pembelajaran sesuai dengan tingkat pemahamannya. (8) Pembelajaran menjadi lebih menarik. (9) Dapat digunakan dalam jenis pembelajaran yang bermacam-macam. Dengan demikian, pembelajaran matematika menjadi lebih interaktif, menarik, dan menyenangkan.

Keunggulan multimedia berbasis komputer ini, menjadikan pembelajaran lebih bermakna, karena multimedia mampu 
menyajikan suatu model pembelajaran yang bersifat interaktif. Berdasarkan pengamatan tersebut, pemanfaatan multimedia pembelajaran berbasis komputer diharapkan mampu meningkatkan motivasi siswa dalam belajar matematika, dan mampu menambah tingkat penguasaan matematika.

Permasalahan yang dihadapi guru di sekolah dalam pemanfaatan multimedia berbasis komputer dalam pembelajaran matematika saat ini adalah kurangnya fasilitas pembelajaran multimedia di sekolah. Sedangkan fasilitas multimedia yang telah tersedia di sekolah merupakan multimedia yang tidak interaktif, sehingga kurang menarik bagi siswa dan menyebabkan siswa menjadi pasif dalam penggunaannya. Keterbatasan ini cukup menyulitkan guru untuk memanfaatkan komputer sebagai media pembelajaran untuk meningkatkan motivasi dan tingkat penguasaan matematika.

Berkaitan dengan adanya kondisi yang seperti tersebut, peneliti tertarik untuk mengembangkan suatu model pembelajaran matematika yang berbantuan komputer yaitu dengan mengembangkan software multimedia pembelajaran matematika yang interaktif bagi siswa kelas VIII SMP yang dapat membantu meningkatkan motivasi siswa untuk mempelajari matematika sehingga dapat meningkatkan pemahaman konsep dan teori matematika secara mandiri maupun berkelompok. Pengembangan software multimedia pembelajaran matematika ini lebih ditekankan pada materi garis singgung lingkaran. Penekanan pada materi ini didasari dari pengalaman peneliti dilapangan pada saat pembelajaran garis singgung lingkaran, persepsi siswa sebagian besar menyatakan bahwa garis singgung lingkaran merupakan sisi miring dari sebuah segitiga yang terbentuk dari komponen panjang garis singgung, jari-jari dan jarak antara titik pusatnya.

\section{Metode Penelitian}

Nana Syaodih Sukmadinata (2006, pp.164-165) menyatakan bahwa penelitian dan pengembangan merupakan proses atau langkah-langkah untuk mengembangkan suatu produk baru atau memodifikasi produk yang telah ada agar menjadi lebih baik secara bertanggungjawab. Produk tersebut tidak hanya berbentuk benda atau perangkat keras (hardware), seperti buku, modul, alat bantu pembelajaran di kelas atau laboratorium, tetapi juga perangkat lunak (software) seperti program komputer yang dapat dimanfaatkan untuk pengolahan data, pembelajaran di kelas, pengelolaan perpustakaan, pengelolaan laboratorium, dan lain-lain.

Penelitian pengembangan merupakan suatu proses untuk mengembangkan dan memvalidasi produk-produk yang dipergunakan dalam proses pembelajaran. Langkah-langkah penelitian dan pengembangan menunjukkan siklus, yang diawali dengan adanya kebutuhan, permasalahan yang membutuhkan pemecahan dengan menggunakan suatu produk tertentu. Langkah selanjutnya adalah menentukan karakteristik atau spesifikasi dari produk yang akan dihasilkan. Setelah itu barulah dibuat draf produk atau produk awal yang kemudian diuji cobakan di lapangan dengan sampel terbatas dan sampel yang lebih luas secara berulang-ulang.

Berdasarkan hasil pengamatan dan evaluasi diadakan penyempurnaan-penyempurnaan. Terdapat berbagai macam model yang dapat dipergunakan untuk mengadakan pengembangan produk "software pembelajaran" sebagai media pembelajaran. Tujuan utama dari penelitian pengembangan ini adalah memperoleh suatu produk "Software" multimedia yang layak untuk pembelajaran matematika untuk siswa kelas VIII SMP berdasarkan KTSP.

Untuk mendapatkan model yang sesuai dengan tujuan ini maka dilakukan adaptasi dari berbagai model. Hal ini dilakukan agar lebih sederhana dan mudah dipahami. Model pengembangan hasil perpaduan tersebut memiliki enam tahap sebagai berikut.

Tahap Pengembangan desain pembelajaran terdiri dari: a) mengidentifikasi kebutuhanpembelajaran dan menulis stan- 
dar kompetensi. Dalam penelitian ini, standar kompetensi yang dipilih adalah menentukan unsur, bagian lingkaran serta ukurannya; b) menulis kompetensi dasar. Kompetensi dasar sudah tertulis di dalam Standar Isi (SI). Dalam penelitian ini, kompetensi dasarnya adalah Menghitung panjang garis singgung persekutuan dua lingkaran; c) menulis tes acuan patokan. Butir-butir tes diperlukan untuk mengukur efektifitas media yang dikembangkan. Butir-butir tes disusun untuk keperluan pretest dan post-test pada tahap uji coba lapangan; d) menyusun strategi pembelajaran. Rencana Pelaksanaan Pembelajaran (RPP) adalah rencana yang menggambarkan prosedur dan pengorganisasian pembelajaran untuk mencapai satu kompetensi dasar yang ditetapkan dalam Standar Isi dan dijabarkan dalam silabus.

Lingkup rencana pembelajaran paling luas mencakup 1 (satu) kompetensi dasar yang terdiri atas 1 (satu) atau beberapa indikator untuk 1 (satu) kali pertemuan atau lebih; e) mengembangkan materi pembelajaran. Materi pembelajaran disusun untuk menunjang pencapaian kompetensi dasar. Untuk dapat mencapai maksud tersebut, penyusunan materi pembelajaran dalam penelitian ini dilakukan dengan mempertimbangkan: (1) potensi siswa; (2) relevansi dengan karakteristik daerah; (3) tingkat perkembangan fisik, intelektual, emosional, sosial, dan spiritual siswa; (4) kebermanfaatan bagi siswa; dan (5) alokasi waktu. f) Mendesain dan melaksanakan evaluasi formatif termasuk merevisi.

Evaluasi formatif bertujuan untuk menentukan apa yang harus ditingkatkan atau direvisi agar produk tersebut lebih efektif dan efisien. Dalam proses pengembangan suatu produk pembelajaran, pelaksanaan evaluasi formatif adalah suatu keharusan. Dengan cara tersebut, pengembang produk pembelajaran menjadi yakin bahwa produk yang dikembangkan efektif dan efisien. Dalam penelitian ini, ada empat tahap evaluasi formatif yang dilakukan, yaitu: (1) review ahli materi dan ahli media; (2) uji coba kelompok kecil; (3) uji coba lapangan.
Tahap pengembangan desain software adalah tahapan mewujudkan desain pembelajaran ke dalam suatu desain program komputer, sehingga dapat dipergunakan sebagai media pembelajaran matematika yang interaktif. Ada beberapa hal yang dilakukan pada tahap ini yaitu: a) menentukan layout; b) mengumpulkan materi; c) menentukan sistem operasi yang sesuai; d) menentukan program aplikasi yang bisa digunakan; e) Menentukan program authoring yang sesuai; $\mathrm{f}$ ) merancang dan mengembangkan storyboard; g) mengumpulkan bahan - bahan baik berupa grafik, image, sound, picture, animasi, file evaluasi, video presentasi, dan sebagainya.

Tahap produksi adalah tahap mengorganisasikan berbagai lay-out, desain, dan macam bahan-bahan yang telah disiapkan menjadi suatu produk multimedia yang interaktif. Langkah - langkah yang ditempuh adalah: a) memproduksi materi pembelajaran matematika. Kegiatan yang dilakukan pada langkah ini adalah memilih gambar- gambar dan menyusunnya sesuai dengan lay out dan desain materi, menyusun program materi pembelajaran, menyusun program evaluasi, menentukan warna, menentukan ilustrasi musik dan suara, membuat feedback positif dan negatif. Kegiatan tersebut dilakukan dengan program Macromedia Flash; b) authoring materi pembelajaran matematika. Untuk dapat menyusun materi yang telah diproduksi maka diperlukan program authoring yang sesuai. Dalam hal ini penulis mempergunakan program Macromedia Flash. Materi yang berupa gambar, suara, grafik, video, animasi, soal evaluasi dan sebagainya disusun secara sistematis sesuai dengan strategi pembelajaran yang telah ditentukan; c) editing materi pembelajaran matematika.

Setelah materi tersusun dengan baik dalam bentuk mutimedia pembelajaran interaktif maka dilakukan editing untuk meneliti desain-desain yang salah ataupun kurang sesuai baik dari segi pengetikan, penggunaan warna, keterbacaan, maupun kemudahan pemakaiannya. 4) Tahap Evaluasi. Pada tahap yang keempat ini diadakan kegiatan evaluasi formatif dan 
sumatif untuk mengetahui tingkat validitas dan reliabilitas materi program pembelajaran, dan tingkat kualitas materi pembelajaran.

Ada beberapa tahap yang ditempuh, yaitu: a) review ahli materi. Review ini dilakukan oleh ahli pendidikan matematika, yaitu dari dosen UNY. Tujuannya adalah untuk mengetahui validitas materi matematika, kebenaran konsep materi, dan kesesuaian materi dengan kompetensi dasar yang akan dicapai; b) review ahli media. Kegiatan ini dilakukan oleh ahli pengembangan media pembelajaran, yaitu dari dosen UNY. Tujuannya adalah untuk mereview dan mengevaluasi kualitas media yang telah disusun baik segi tampilan, daya tarik, kebenaran konsep media, dan sebagainya; c) uji coba pada siswa. Setelah menganalisis hasil review dari ahli materi dan ahli media dan merevisi produk berdasarkan hasil review tersebut, dilakukan uji coba kelompok kecil kepada 5 siswa dan meminta penilaiannya melalui kuesioner.

Data yang diberikan siswa melalui angket, kritik, dan saran digunakan sebagai dasar perbaikan multimedia. Setelah menganalisis hasil penilaian siswa dan melakukan revisi produk berdasarkan penilaian siswa pada uji coba kelompok kecil, dilakukan uji coba kelompok besar/uji coba lapangan. Hal tersebut dilakukan untuk menguji tingkat kualitas produk yang lebih mendalam, dengan setting lingkungan seperti situasi pembelajaran matematika menggunakan multimedia pada umumnya. Setelah itu, meminta penilaiannya tentang kualitas multimedia tersebut melalui kuesioner.

Pada tahap ini dilaksanakan uji kompetensi untuk mengetahui ketuntasan belajar siswa. Apabila hasil uji kompetensi diperoleh $\geq 75 \%$ responden mencapai KKM (Kriteria Ketuntasan Minimal), maka multimedia pembelajaran yang dikembangkan layak untuk digunakan. Sebaliknya, apabila hasil uji kompetensi diperoleh bahwa $<75 \%$ responden mencapai KKM, maka dilakukan uji coba lagi.
Tahap revisi, dari hasil evaluasi pada tahap empat diperoleh data tentang validitas media, kelemahan media, respon terhadap media, dan kritikan maupun saran dari para ahli materi dan ahli media. Berbagai macam data tersebut kemudian dianalisis untuk mengetahui kelemahan dan keunggulan dari media yang dibuat. Sehingga, dapat ditentukan bagian mana saja yang harus ditingkatkan, diganti, maupun diteruskan. Dari hasil analisis diadakan revisi baik revisi pada desain software multimedia pembelajaran maupun revisi pada desain instruksionalnya.

Tahap Pemanfaatan dan penyebarluasan, Setelah produk multimedia pembelajaran tersebut dianalisis dan direvisi maka diharapkan diperoleh suatu produk yang valid dan berkualitas. Langkah selanjutnya yang ditempuh adalah pemanfaatan media tersebut dalam kegiatan pembelajaran di SMP, dan dikembangkan lebih lanjut serta disebarluaskan pada para guru SMP untuk dimanfaat dalam pembelajaran.

\section{Subjek Uji Coba}

Subyek uji coba dalam penelitian ini adalah 5 orang siswa kelas VIII C SMP Negeri 4 Depok Sleman yang diambil secara acak untuk uji coba kelompok kecil, 36 siswa klas VIII D siswa SMP Negeri 4 Depok Sleman untuk uji coba lapangan sebagai kelas eksperimen. Untuk mengetahui efektifitas produk yang dikembangkan diambil 35 siswa kelas VIII B SMP N 4 Depok Sleman sebagai kelas kontrol dengan disampaikan pembelajaran secara konvensional.

Untuk validasi produk multimedia yang dikembangkan dari aspek pembelajaran dan materi, dipilih satu orang ahli materi yaitu Drs. Edi Prajitno, M.Pd., dosen jurusan Pendidikan Matematika Fakultas MIPA Universitas Negeri Yogyakarta. Untuk validasi produk multimedia yang dikembangkan dari aspek media, dipilih satu orang ahli media yaitu Herman Dwi Suryono, Ph.D., dosen program studi Teknologi Pembelajaran Program Pascasarjana Universitas Negeri Yogyakarta. 
Instrumen Pengumpulan Data

Instrumen yang digunakan dalam penelitian untuk mengetahui kualitas multimedia pembelajaran matematika dari aspek pembelajaran, materi, dan media. Pengukuran kualitas multimedia pembelajaran matematika digunakan dua macam instrumen; a) kuesioner, digunakan untuk mengukur kualitas multimedia pembelajaran yang dikembangkan, dari aspek pembelajaran, materi, dan media; b) uji kompetensi digunakan untuk mengetahui jumlah persentase siswa yang sudah mencapai ketuntasan belajar, setelah menggunakan multimedia pembelajaran hasil pengembangan.

\section{Teknik Analisis Data}

Data mengenai tanggapan siswa yang dikumpulkan melalui kuesioner dianalisis dengan statistik deskriptif. Hasil angket dianalisis dengan kriteria seperti Tabel 1 sebagai berikut.

Tabel 1. Kategori Skor pada skala 5

\begin{tabular}{ccc}
\hline Kategori & Simbol & Skor \\
\hline Sangat Baik & SB & 5 \\
Baik & B & 4 \\
Cukup & C & 3 \\
Kurang & K & 2 \\
Sangat Kurang & SK & 1 \\
\hline
\end{tabular}

Setelah itu hasilnya dikonversikan menjadi nilai, pada skala 5 (Sukardjo, 2005, p.55) yang disajikan pada Tabel 2.

Tabel 2. Konversi Skor ke Nilai pada skala 5

\begin{tabular}{cc}
\hline Interval skor & Kategori \\
\hline $\bar{X}_{\mathrm{i}}+1,80 \mathrm{SBi}<\mathrm{X}$ & Sangat \\
$\bar{X}_{\mathrm{i}}+0,60 \mathrm{SBi}<\mathrm{X} \leq \bar{X}_{\mathrm{i}}+1,80 \mathrm{SBi}$ & Baik \\
$\bar{X}_{\mathrm{i}}-0,60 \mathrm{SBi}<\mathrm{X} \leq \bar{X}_{\mathrm{i}}+0,60 \mathrm{SBi}$ & Cukup \\
$\bar{X}_{\mathrm{i}}-1,80 \mathrm{SBi}<\mathrm{X} \leq \bar{X}_{\mathrm{i}}-0,60 \mathrm{SBi}$ & Kurang \\
$\mathrm{X} \leq \bar{X}_{\mathrm{i}}-1,80 \mathrm{SBi}$ & Sangat \\
\hline
\end{tabular}

Keterangan:

$\bar{X}_{\mathrm{i}}:$ Rerata ideal $=\frac{1}{2}$ (skor maksimal ideal + skor minimal ideal)
$\mathrm{SB}_{\mathrm{i}} \quad$ : Simpangan baku ideal $=\frac{1}{6}$ (skor

maksimal ideal - skor minimal ideal)

X : Skor hasil uji coba

Dari perbandingan skor tersebut diperoleh standar kualitas produk media pembelajaran dengan rincian sebagai berikut: 1) Produk media pembelajaran yang dikembangkan dinyatakan sangat baik bila rata - rata skor yang diperoleh dari 4,22 sampai dengan 5,00. 2) Produk media pembelajaran yang dikembangkan dinyatakan baik bila rata- rata skor yang diperoleh dari 3,41 sampai dengan 4,21. 3) Produk media pembelajaran yang dikembangkan dinyatakan cukup bila rata rata skor yang diperoleh dari 2,61 sampai dengan 3,40. 4) Produk media pembelajaran yang dikembangkan dinyatakan kurang bila rata - rata skor yang diperoleh dari 1,79 sampai dengan 2,60. 5) Produk media pembelajaran yang dikembangkan dinyatakan sangat kurang bila rata - rata skor yang diperoleh dari 1 sampai dengan 1,78 .

Pedoman pengubahan data kuantitatif menjadi data kualitatif dapat dipaparkan dalam tabel berikut ini.

Tabel 3. Pedoman Pengubahan Data

Kuantitatif Menjadi Data Kualitatif

\begin{tabular}{cc}
\hline Interval Skor & Kategori \\
\hline $4,21<X$ & Sangat Baik \\
$3,40<X \leq 4,21$ & Baik \\
$2,60<X \leq 3,40$ & Cukup \\
$1,79<X \leq 2,60$ & Kurang \\
$X \leq 1,79$ & Sangat Kurang \\
\hline
\end{tabular}

Keterangan :

Skor maksimal $=5$

$\bar{X}_{\mathrm{i}}=\frac{1}{2}(5+1)=3$

Skor minimal $=1$

$\mathrm{SBi}=\frac{1}{6}(5-1)=0,67$

$\mathrm{X}=$ Skor aktual

Sedangkan untuk memperoleh skor rata-rata penilaian terhadap multimedia pembelajaran hasil pengembangan menggunakan rumus sebagai berikut:

$$
\bar{X}=\frac{\sum X}{n}
$$


Keterangan :

$$
\begin{aligned}
\bar{X} & =\text { Rata-rata skor } \\
\sum_{n} X & =\text { Jumlah skor } \\
& =\text { Banyaknya responden }
\end{aligned}
$$

Dengan demikian, skor tiap butir tanggapan yang diperoleh dapat dikonversikan menjadi nilai untuk mengetahui kategori setiap butir tanggapan atau ratarata secara keseluruhan terhadap multimedia pembelajaran hasil pengembangan. Pada penelitian pengembangan ini, peneliti memberi nilai kelayakan produk multimedia pembelajaran hasil pengembangan minimal dengan kategori baik, sehingga hasil penilaian, baik dari ahli materi, ahli media maupun siswa, jika sudah memberikan hasil penilaian akhir (keseluruhan) dengan kategori minimal "Baik", maka produk multimedia pembelajaran hasil pengembangan tersebut sudah dianggap layak digunakan.

Untuk mengetahui tingkat ketuntasan belajar siswa, peneliti menggunakan kriteria ketuntasan minimal 75 (KKM pada kompetensi dasar 4.4. menghitung panjang garis singgung persekutuan dua lingkaran mata pelajaran matematika kelas VIII di SMP Negeri 4 Depok), sehingga apabila siswa pada uji kompetensi mendapat nilai minimal 75, siswa tersebut dinyatakan sudah tuntas pada materi tersebut. Jika persentase ketuntasan belajar siswa $\geq$ 60,4\% (kategori baik), maka produk multimedia pembelajaran hasil pengembangan tersebut sudah dianggap layak digunakan

Pedoman pengubahan data persentase ketuntasan belajar menjadi data kualitatif, dipaparkan dalam Tabel 4 .

Tabel 4. Pedoman Pengubahan Data Persentase Ketuntasan Belajar menjadi Data Kualitatif

\begin{tabular}{cc}
\hline $\begin{array}{c}\text { Interval Persentase } \\
\text { Ketuntasan Belajar }\end{array}$ & Kategori \\
\hline $80,2<X$ & Sangat Baik \\
$60,4<X \leq 80,2$ & Baik \\
$40,6<X \leq 60,4$ & Cukup \\
$20,8<X \leq 40,6$ & Kurang \\
$X \leq 20,8$ & Sangat Kurang \\
\hline
\end{tabular}

Keterangan:

Persentase maksimal $=100$

$\bar{X}_{\mathrm{i}}=\frac{1}{2}(100+1)=50,5$

Persentase minimal $=1$

$\mathrm{SBi}=\frac{1}{6}(100-1)=16,5$

$\mathrm{X}=$ Persentase aktual

Untuk mengetahui efektifitas produk yang dikembangkan, digunakan desain penelitian eksperimen yaitu Desain Kelompok Kontrol Pratest-Pasca Tes (Randomized Pretest-Posttest Control Group Design) (Sukmadinata, 2006, p.204) seperti pada gambar berikut ini.

\begin{tabular}{|lllll|}
\hline Kelompok & Prates & & Perlakuan & Pascates \\
Eksperimen & $\mathrm{O}$ & $\longrightarrow$ & $\mathrm{X}$ & \\
Kontrol & $\mathrm{O}$ & & & 0 \\
\hline
\end{tabular}

Gambar 1. Desain Kelompok Kontrol Prates-Pascates Beracak

Kelompok eksperimen dan kelompok kontrol diberi tes awal (pretest) dengan tes yang sama. Kemudian kelompok eksperimen diberi perlakuan khusus yaitu diminta mempelajari materi dari produk pengembangan, sedangkan kelompok kontrol diberi perlakuan biasa yaitu dengan mempelajari materi secara konvensional. Setelah diberi perlakuan masing-masing, kedua kelompok dites dengan tes yang sama sebagai tes akhir (posttest). Hasil kedua tes akhir dibandingkan, demikian juga antara hasil tes awal dan tes akhir masing-masing kelompok.

\section{Hasil Penelitian}

Desain Materi

Hasil analisis kebutuhan, karakteristik siswa dan pengalaman penulis, ditetapkan materi pokok yang dikembangkan adalah dalam penelitian pengembangan ini adalah standar kompentensi 4, menentukan unsur, bagian lingkaran serta ukurannya dengan kompetensi dasar 4.4, menghitung panjang garis singgung persekutuan dua lingkaran. Berdasarkan pengalaman penulis, sebagian besar siswa 
mempersepsikan bahwa jarak antara dua pusat lingkaran dinyatakan sebagai sisi siku-siku pada segitiga yang terbentuk dari hasil pergeserannya sementara panjang garis singgung persekutuan kedua lingkaran dipersepsikan sebagai sisi miring, sementara yang benar adalah sebaliknya. Sehingga diperlukan suatu animasi pergeseran garis yang dapat memperjelas kondisi tersebut.

\section{Desain Software}

Desain software dilakukan dengan 2 tahap yaitu: 1) tahap pendahuluan. Jenis aplikasi multimedia yang ditentukan adalah Macromedia Flash 8, lay out dasar warna dan jenis huruf (font) disesuaikan dengan latar belakang (background), jenis huruf (font) yang digunakan sebagian besar Script MT Bolt dan Time New Roman. Sistem dan alur operasi yang digunakan adalah sistem paralel; 2) tahap pengembangan desain. Pada tahap ini pengembangan alur cerita (storyboard) dan rancangan awal (prototype).

Produksi

Tahapan produksi dilaksanakan dalam tiga langkah, yaitu: 1) pembuatan materi. Kegiatannya adalah pengetikan materi pembelajaran, pengetikan soal evaluasi, pemilihan gambar, button, clip-art, sound, musik; 2) pengorganisasian materi. Tujuannya adalah mengintegrasikan semua materi yang telah dibuat ke dalam screen, sesuai dengan storyboard yang telah dibuat, dengan menggunakan program Macromedia Flash Profesional 8; 3) evaluasi produk awal. Pada tahapan ini dilakukan penjujian tentang keberfungsian tombol dan jalannya animasi. Tujuannya adalah melakukan pengeditan terhadap tampilan multimedia yang dikembangkan, sebelum diuji cobakan kepada subyek penelitian

Evaluasi

Tahapan ini dilaksanakan dengan tujuan untuk mendapatkan umpan balik dari subyek penelitian tentang kualitas multimedia yang dikembangkan. Langkahlangkah dalam tahapan ini adalah sebagai berikut: 1) evaluasi oleh ahli materi dalam rangka mengetahui kualitas multimedia yang dikembangkan ditinjau dari aspek materi dan pembelajaran; 2) evaluasi oleh ahli media dalam rangka mengetahui kualitas multimedia yang dikembangkan ditinjau dari aspek media; 3) uji coba kelompok kecil, yang dilakukan terhadap 5 orang siswa; 4) uji coba kelompok besar/ uji coba lapangan, yang dilakukan terhadap 36 orang siswa.

\section{Revisi}

Tahapan revisi dilakukan setelah setiap tahapan evaluasi dilaksanakan. Dari hasil evaluasi oleh ahli materi dan ahli media dilakukan revisi berdasarkan temuan, masukan, dan saran perbaikan yang tertera dalam angket. Dari hasil uji coba, baik uji coba kelompok kecil maupun uji coba lapangan dilakukan revisi berdasarkan komentar dan masukan responden yang tertera dalam angket. Dari hasil uji coba lapangan diperoleh data sebagai acuan dalam menentukan kelayakan dari multimedia yang dikembangkan

\section{Pemanfaatan dan Penyebarluasan}

Kegiatan pemanfaatan dan penyebaran dilakukan dalam forum MGMP Matematika SMP/MTs di kabupaten Sleman yaitu dengan memaparkan produk pengembangan dan membagikan CD hasil pengembangan. Kegiatan ini diikuti oleh 15 pengurus MGMP Matematika SMP/MTs di kabupaten Sleman.

\section{Pembahasan Hasil Penilaian Ahli Materi}

Ahli materi memberikan penilaian pada aspek materi dengan nilai rata-rata 4,00 termasuk kriteria "Baik" dan pada aspek pembelajaran dengan nilai rata-rata 4,11 termasuk kriteria "Baik". Rata-rata skor keseluruhan dari aspek pembelajaran dan aspek materi yaitu: 4,06 setelah dikonversikan ke skala 5 termasuk kriteria "Baik". Sesuai saran dari ahli materi untuk penyempurnaan produk, telah dilakukan revisi dan hasil revisi dapat dilihat pada pembahasan revisi produk. Berdasarkan 
hasil penilaian dari ahli materi, produk multimedia pembelajaran matematika ini dinyatakan layak untuk diujicobakan di lapangan.

\section{Pembahasan Hasil Penilaian Ahli Media}

Ahli media memberikan penilaian dengan skor rata-ratanya 4,08 setelah dikonversikan ke skala 5 termasuk kategori "Baik". Sesuai saran dari ahli media untuk penyempurnaan produk, telah dilakukan revisi dan hasil revisi dapat dilihat pada pembahasan revisi produk. Berdasarkan hasil penilaian dari ahli materi, produk multimedia pembelajaran matematika ini dinyatakan layak untuk diujicobakan di lapangan.

\section{Pembahasan Hasil Uji Coba Kelompok Kecil}

Ada tiga aspek yang dianalisis pada uji coba kelompok kecil, yaitu: aspek materi, aspek pembelajaran, dan aspek media. Dari data yang telah disajikan sebelumnya, dapat dijelaskan bahwa skor rata-rata untuk aspek materi yaitu 3,73 setelah dikonversi dari skor ke nilai pada skala 5 seperti yang tertera pada tabel 3, berarti termasuk kategori "Baik". Demikian juga skor rata-rata untuk aspek pembelajaran yaitu 3,80 setelah dikonversikan termasuk kategori "Baik", dan skor ratarata aspek media yaitu 3,70 setelah dikonversikan termasuk kategori "Baik". Skor rata-rata keseluruhan yaitu 3,74 setelah dikonversikan termasuk kategori "Baik".

Berdasarkan hasil analisis uji coba kelompok kecil, dapat dikatakan bahwa produk multimedia pembelajaran matematika hasil pengembangan ditinjau dari aspek materi, aspek pembelajaran maupun aspek media termasuk dalam kategori "Baik", sehingga layak untuk digunakan pada uji coba kelompok besar.

\section{Pembahasan Hasil Tes Awal (Pretest)}

Berdasarkan hasil tes awal (pretest) baik untuk kelompok kontrol maupun kelompok eksperimen diperoleh data sebagai berikut: 1) rata-rata skor untuk 35 responden kelompok kontrol adalah
55,430, sedangkan rata-rata skor untuk 36 responden kelompok eksperimen adalah 54,67 ; 2) banyak siswa yang telah tuntas (KKM 75) untuk kelompok kontrol ada 5 $(14,29 \%)$ sedangkan banyak siswa yang telah tuntas untuk kelompok eksperimen ada $5(13,89 \%)$.

\section{Pembahasan Hasil Uji Coba Lapangan}

\section{Aspek Pembelajaran}

Dari responden sebanyak 36 siswa yang memberikan penilaian terhadap produk multimedia pembelajaran matematika hasil pengembangan dari aspek materi, diperoleh rata-rata skor keseluruhan yaitu 3,99 setelah dikonversikan pada skala 5 termasuk kategori "Baik".

Sedangkan penjelasan tiap butir, dipaparkan secara detail sebagai berikut: 1) Pada butir kejelasan materi, responden memberikan skor rata-rata penilaian sebesar 4,00 setelah dikonversikan pada skala 5 termasuk kategori "Baik". 2) Pada butir kemenarikan materi yang dipelajari, responden memberikan skor rata-rata penilaian sebesar 4,22 setelah dikonversikan pada skala 5 termasuk kategori "Sangat baik". 3) Pada butir kejelasan penggunaan bahasa, responden memberikan skor rata-rata penilaian sebesar 3,92 setelah dikonversikan pada skala 5 termasuk kategori "Baik". 4) Pada butir kemudahan materi yang dipelajari, responden memberikan skor rata-rata penilaian sebesar 3,72 setelah dikonversikan pada skala 5 termasuk kategori "Baik".

Selanjutnya, 5) pada butir kejelasan kalimat pada uraian materi, responden memberikan skor rata-rata penilaian sebesar 3,72 setelah dikonversikan pada skala 5 termasuk kategori “Baik". 6) Pada butir kejelasan petunjuk pengerjaan soal, responden memberikan skor rata-rata penilaian sebesar 3,89 setelah dikonversikan pada skala 5 termasuk kategori "Baik". 7) Pada butir tingkat kesulitan soal, responden memberikan skor rata-rata penilaian sebesar 3,83 setelah dikonversikan pada skala 5 termasuk kategori "Baik". 8) Pada butir kejelasan tulisan, responden 
memberikan skor rata-rata penilaian sebesar 4,11 setelah dikonversikan pada skala 5 termasuk kategori "Baik". 9) Pada butir kemanfaatan gambar, responden memberikan skor rata-rata penilaian sebesar 4,47 setelah dikonversikan pada skala 5 termasuk kategori "Sangat baik". Secara umum pada aspek materi, responden memberikan skor rata-rata 3,99 setelah dikonversikan pada skala 5 termasuk kategori "Baik".

\section{Aspek Materi}

Dari responden sebanyak 36 siswa yang memberikan penilaian terhadap produk multimedia pembelajaran matematika hasil pengembangan dari aspek materi, diperoleh rata-rata skor keseluruhan 4,04 setelah dikonversikan pada skala 5 termasuk kategori "Baik".

Penjelasan tiap butir, dipaparkan secara detail sebagai berikut: 1) pada butir kejelasan petunjuk belajar, responden memberikan skor rata-rata penilaian sebesar 4,03 setelah dikonversikan pada skala 5 termasuk kategori “Baik". 2) Pada butir kejelasan rumusan kompetensi belajar, responden memberikan skor rata-rata penilaian sebesar 3,94 setelah dikonversikan pada skala 5 termasuk kategori "Baik". 3) Pada butir kemudahan untuk mempelajari materi, responden memberikan skor ratarata penilaian sebesar 4,11 setelah dikonversikan pada skala 5 termasuk kategori "Baik". 4) Pada butir keruntutan materi, responden memberikan skor rata-rata penilaian sebesar 4,14 setelah dikonversikan pada skala 5 termasuk kategori "Baik".

Selanjutnya, 5) pada butir kejelasan contoh soal yang diberikan, responden memberikan skor rata-rata penilaian sebesar 4,06 setelah dikonversikan pada skala 5 termasuk kategori "Baik". 6) Pada butir kesesuaian contoh soal dengan materi, responden memberikan skor rata-rata penilaian sebesar 4,06 setelah dikonversikan pada skala 5 termasuk kategori "Baik". 7) Pada butir kejelasan petunjuk mengerjakan soal, responden memberikan skor rata-rata penilaian sebesar 3,97 setelah dikonversikan pada skala 5 termasuk kategori "Baik". 8) Pada butir kecukupan soal untuk pemahaman materi, responden memberikan skor rata-rata penilaian sebesar 3,86 setelah dikonversikan pada skala 5 termasuk kategori "Baik". 9) Pada butir respon terhadap jawaban benar/salah, responden memberikan skor rata-rata penilaian sebesar 4,22 setelah dikonversikan pada skala 5 termasuk kategori "Sangat baik".

Secara umum pada aspek pembelajaran, responden memberikan skor ratarata 4,04 setelah dikonversikan pada skala 5 termasuk kategori "Baik".

\section{$\underline{\text { Aspek Media }}$}

Dari responden sebanyak 36 siswa yang memberikan penilaian terhadap produk multimedia pembelajaran matematika hasil pengembangan dari aspek media, diperoleh rata-rata skor keseluruhan 3,96 setelah dikonversikan pada skala 5 termasuk kategori "Baik".

Penjelasan tiap butir, dipaparkan secara detail sebagai berikut: 1) pada butir kejelasan petunjuk penggunaan media, responden memberikan skor rata-rata penilaian sebesar 4,08 setelah dikonversikan pada skala 5 termasuk kategori "Baik"; 2) pada butir keterbacaan tulisan, responden memberikan skor rata-rata penilaian sebesar 4,11 setelah dikonversikan pada skala 5 termasuk kategori "Baik"; 3) pada butir kejelasan/kualitas gambar, responden memberikan skor rata-rata penilaian sebesar 4,28 setelah dikonversikan pada skala 5 termasuk kategori "Sangat baik"; 4) pada butir ketepatan pemilihan jenis dan ukuran tulisan, responden memberikan skor ratarata penilaian sebesar 3,64 setelah dikonversikan pada skala 5 termasuk kategori "Baik".

Selanjutnya, 5) pada butir ketepatan pemilihan warna, responden memberikan skor rata-rata penilaian sebesar 3,83 setelah dikonversikan pada skala 5 termasuk kategori "Baik"; 6) pada butir tampilan tiap slide, responden memberikan skor rata-rata penilaian sebesar 4,22 setelah 
dikonversikan pada skala 5 termasuk kategori "Sangat baik"; 7) pada butir daya dukung musik pengiring, responden memberikan skor rata-rata penilaian sebesar 3,22 setelah dikonversikan pada skala 5 termasuk kategori "Baik"; 8) pada butir kebebasan memilih menu, responden memberikan skor rata-rata penilaian sebesar 3,94 setelah dikonversikan pada skala 5 termasuk kategori "Baik"; 9) pada butir kemudahan memilih menu, responden memberikan skor rata-rata penilaian sebesar 4,25 setelah dikonversikan pada skala 5 termasuk kategori "Sangat baik". 10) Pada butir kejelasan fungsi tombol, responden memberikan skor rata-rata penilaian sebesar 3,94 setelah dikonversikan pada skala 5 termasuk kategori "Baik".

Selanjutnya, 11) pada butir ketepatan pemilihan animasi, responden memberikan skor rata-rata penilaian sebesar 3,89 setelah dikonversikan pada skala 5 termasuk kategori "Baik"; 12) pada butir kecukupan soal latihan dan evaluasi, responden memberikan skor rata-rata penilaian sebesar 4,08 setelah dikonversikan pada skala 5 termasuk kategori "Baik".

Secara umum pada aspek media, responden memberikan skor rata-rata 3,96 setelah dikonversikan pada skala 5 termasuk kategori "Baik". Dari hasil analisis data uji coba kelompok besar, dapat dikatakan bahwa produk multimedia pembelajaran matematika hasil pengembangan ditinjau dari aspek materi, aspek pembelajaran maupun aspek media termasuk dalam kategori "Baik".

\section{Pembahasan Efektifitas Produk Pengembangan}

Untuk mengetahui efektifitas produk pengembangan pada penelitian ini dilakukan dengan membandingkan hasil uji kompetensi dari tes awal (pretest) dan tes akhir (posttest) pada saat uji coba lapangan untuk kelompok eksperimen dengan hal yang sama untuk kelompok kontrol. Perbandingan tersebut berdasarkan kenaikan nilai rata-rata dan kenaikan ketuntasan belajar pada masing-masing kelompok.
Uji kompetensi adalah proses yang dilakukan untuk mengukur pencapaian kompetensi siswa secara berkelanjutan dalam proses pembelajaran, untuk memantau kemajuan, melakukan perbaikan pembelajaran, dan menentukan keberhasilan belajar siswa. Uji kompetensi yang dimaksud adalah tes akhir (posttest). Pencapaian kompetensi seorang siswa dapat dilihat dari keberhasilan siswa tersebut dalam mencapai nilai KKM (Kriteria Ketuntasan Mimimal). Untuk KKM mata pelajaran matematika kelas VIII pada kompetensi dasar menghitung panjang garis singgung persekutuan dua lingkaran di SMP Negeri 4 Depok tahun pelajaran 2012/2013 ditetapkan sebesar "75". Sehingga, apabila seorang siswa mendapat nilai minimal 75 dikatakan telah mencapai ketuntasan belajar.

Dari kelompok kontrol yang mengikuti tes akhir (posttest) setelah dilaksanakan pembelajaran konvensional sesuai dengan rencana pelaksanaan pembelajaran yang sudah disetujui oleh guru mata pelajaran matematika kelas VIII SMP N 4 Depok dan dari kelompok eksperimen setelah dilaksanakan pembelajaran dengan multimedia pembelajaran matematika hasil pengembangan diperoleh hasil sebagai berikut: 1) rata-rata skor untuk 35 responden kelompok kontrol adalah 78,14, sedangkan rata-rata skor untuk 36 responden kelompok eksperimen adalah 88,06. 2) Banyak siswa yang telah tuntas (nilai diatas KKM 75) untuk kelompok control ada $21(60 \%)$ sedangkan banyak siswa yang telah tuntas untuk kelompok eksperimen ada $31(86,11 \%)$.

\section{Simpulan Dan Saran}

Simpulan

Pengembangan multimedia pembelajaran matematika dalam penelitian ini telah dilaksanakan dengan menggunakan model adaptasi pengembangan produk dari M. Atwi Suparman (2001: p. 11), Criswell (1989: p. 50), Dick, Carey, \& Carey (2005: pp. 282-291), dan model Borg \& Gall (1983: p. 775). Berdasarkan hasil analisis 
data penelitian dan pengembangan menghasilkan kesimpulan hasil penelitian sebagai berikut: 1) multimedia pembelajaran matematika dikembangkan berdasarkan tahapan-tahapan: desain materi, desain software, produksi, evaluasi, revisi serta pemanfaatan dan penyebarluasan; 2) tanggapan ahli materi terhadap multimedia pembelajaran matematika ini dari aspek materi maupun pembelajaran adalah baik. Skor rata-rata dari aspek materi adalah 4,00 dan aspek pembelajaran adalah 4,11 yang berarti termasuk kategori "baik".

Tanggapan ahli media terhadap multimedia pembelajaran matematika ini adalah baik. Skor rata-rata dari aspek media adalah 4,08 yang berarti termasuk kategori "baik". Tanggapan siswa dalam tahap ujicoba kelompok kecil, skor ratarata dari aspek materi adalah 3,73 yang berarti termasuk kategori "baik", skor ratarata dari aspek pembelajaran adalah 3,80 yang berarti termasuk kategori "baik", skor rata-rata dari aspek media adalah 3,70 yang berarti termasuk kategori "baik" .

Tanggapan siswa dalam tahap uji coba kelompok besar, skor rata-rata dari aspek materi adalah 3,99 yang berarti termasuk kategori "baik", skor rata-rata dari aspek pembelajaran adalah 4,04 yang berarti termasuk kategori "baik", skor ratarata dari aspek media adalah 3,96 yang berarti termasuk kategori "baik". Jadi multimedia yang dikembangkan layak digunakan dalam pembelajaran matematika kelas VIII SMP. 3) Berdasarkan hasil tes awal (pretest)dan tes akhir (posttest) terhadap kelompok kontrol dan kelompok eksperimen diperoleh rata-rata skor peningkatan dan persentase ketuntasan sebagai berikut: a) Skor rata-rata pada kelompok kontrol meningkat 22,71 dari 55,43 menjadi 78,14 dan persentase ketuntasan meningkat $45,71 \%$ dari dari $14,29 \%$ menjadi $60,00 \%$. b) Skor rata-rata pada kelompok eksperimen meningkat 33,39 dari 54,67 menjadi 88,06 dan persentase ketuntasan meningkat $72,22 \%$ dari dari $13,89 \%$ menjadi $86,11 \%$.

Setelah menggunakan multimedia pembelajaran matematika hasil pengem- bangan, rata-rata skor hasil uji kompetensi pada saat uji coba lapangan lebih tinggi 10,68 dan persentase ketuntasan lebih tinggi $26,51 \%$ jika dibanding dengan pembelajaran konvensional. Hal ini berarti, multimedia hasil pengembangan lebih efektif digunakan dalam pembelajaran matematika kelas VIII SMP.

Saran

Berdasarkan kesimpulan hasil penelitian yang terdiri dari tanggapan ahli materi, tanggapan ahli media, tanggapan siswa dengan hasil baik dan jumlah persentase siswa yang mencapai ketuntasan belajar setelah menggunakan multimedia hasil pengembangan dengan hasil sangat baik, maka produk multimedia pembelajaran hasil pengembangan ini disarankan untuk dapat dimanfaatkan siswa maupun guru dalam pembelajaran matematika, sehingga siswa mendapatkan model pembelajaran yang berbeda dari pembelajaran konvensional yang biasa dilakukan oleh guru.

Kegiatan pembelajaran dengan multimedia ini dapat dilakukan secara mandiri maupun berkelompok. Produk akkhir multimedia pembelajaran ini dikemas dalam bentuk $C D$ interaktif yang rencananya akan disebarluaskan kepada semua pengguna. Untuk tahap awal direncanakan penyebarluasan melalui pertemuan MGMP (Musyawarah Guru Mata Pelajaran) Matematika di Kabupaten Sleman.

Dengan harapan melalui guru-guru tersebut produk multimedia pembelajaran matematika hasil pengembangan ini diimplementasikan di sekolah masing-masing. Multimedia pembelajaran yang dikembangkan dalam penelitian ini, masih terbatas hanya satu kompetensi dasar dengan materi garis singgung lingkaran. Untuk itu, perlu dikembangkan multimedia pembelajaran lebih lanjut yang memuat kompetensi dasar yang lain.

\section{Daftar Pustaka}

Borg, W.R., \& Gall, M. D., (1983). Educational research: An introduction. New York: Longman Inc. 
Criswell, E. L., (1989). The design of computer-based instruction. New York: Machmillan Publishing Company.

Depdiknas. (2006). Panduan Materi Matematika SMP/MTs - Kurikulum 2006.

Dick, W., Carey, L., \& Carey, J.O. (1985) The systematic design of instruction. New York: Scott, Foresmen and Company

Gall, M.D., Gall, J.P., \& Borg, W.R., (1983). Educational research: An introduction. New York:

Newby, Timothy J, et al. (2000). Instructional technology for teaching and learning. Upper Saddle River, New Jersey : Prentice-hall, Inc, Pearson Education

Sadiman, A.S., dkk. (2006). Media pendidikan: pengertian, pengembangan, dan pemanfaatannya. Jakarta: Pustekkom Diknas \& Raja Grafindo Perkasa.

Seel, B. Barbara \& Richey, C. Rita. (1994). Instruction technology: the definition and domain of the field. Washington D.C: Association for Educational Communications Technology (AECT).

Sujana, N. (1991). Teori belajar untuk pengajaran. Jakarta: Lembaga Penerbit Fakultas Ekonomi Universitas Indonesia.

Sukardjo. (2005). Evaluasi pembelajaran. Diktat mata kuliah evaluasi pembelajaran. Yogyakarta: Prodi TP PPs UNY. Tidak Diterbitkan

Sukmadinata, N. S. (2006). Pengembangan kurikulum teori dan praktek. Bandung: PT Remaja Rosdakarya Offset. 